\title{
Demokrat Parti Dönemi Maraş Basını ${ }^{1}$
}

\author{
Cengiz ŞAVKILI \\ Dr. Öğr. Üyesi, Kahramanmaraş Sütçü İmam Üniversitesi, \\ Fen Edebiyat Fakültesi, Tarih Bölümü \\ savkili67@ksu.edu.tr \\ Orcid ID: https://orcid.org/0000-0002-7083-7020
}

\author{
Ali AKYILDIZ \\ Öğr. Gör., Kahramanmaraş Sütçü İmam Üniversitesi, \\ Atatürk İlkeleri Ve İnkılâp Tarihi Bölümü \\ akyildiz461@hotmail.com \\ Orcid ID: https://orcid.org/0000-0002-4593-8452
}

\begin{abstract}
Öz
Demokrat Parti'nin kurulmasıyla birlikte Türkiye'de çok partili siyasi hayata geçilmiştir. Demokrat Parti kuruluş aşamasında ve iktidarının ilk yıllarında basına karşı liberal politika anlayışını taşımaktaydı. Bunun sonucunda Maraş basınında Engizek, Kahraman Yurt, Demokrasiye Hizmet gibi gazeteler yayın hayatına başlamıştır. Süreç içerisinde Demokrat Parti'nin basına karşı politikalarında bazı değişmeler yaşanmış ve bunun sonucunda basına karşı belli yaptırımlar uygulanmıştır. Bu uygulamalar gazetelerin muhalif ve iktidar yanlısı olarak yorumlanmasına etki etmiştir. Bu çalışmanın amacı Demokrat Parti’nin basın politikasının Maraş'a yansımasını ortaya koymaktır. Makalede siyasi yorum ve haberlere sayfalarında genişçe yer veren Engizek, Demokrasiye Hizmet, Maraşın Sesi, Halk Postası ve Kahraman Yurt gazeteleri taranmıştır. Ayrıca Demokrat Parti Döneminde yayın yapan Yeni Maraş, Kurtuluş gibi gazetelerin sınırlı sayılarının olması, bu gazetelerden istenilen ölçüde istifade etmeyi engellemiştir. Neticede yapılan değerlendirmelerden Demokrat Parti Döneminde Maraş basınının aktif bir yayın hayatı yaşadığı sonucuna ulaşılmıştır.
\end{abstract}

Anahtar Kelimeler: Maraş, Yerel Gazeteler, Demokrat Parti.

\footnotetext{
${ }^{1}$ Makale Geliş/Kabul Tarihi: 14.05.2019 / 26.07.2019

Künye Bilgisi: Şavkıll, C., Akyıldız, A. (2019). Demokrat Parti Dönemi Maraş Basinı. Kahramanmaraş Sütçü Imam Üniversitesi Sosyal Bilimler Dergisi, 16 (2), 757-776. DOI: 10.33437/ksusbd.565144
} 


\title{
The Media of Maras During the Democratic Party Period
}

\begin{abstract}
The establishment of the Democratic Party led to the start of multi- party life in Turkish political life. The Democrat Party followed a liberal policy against the press during its establishment and in its early years. As a result of this newspapes such as Engizek, Kahraman Yurt, Demokrasiye Hizmet begun publsihed. Inn process, the Democrat Party imposed certain sanction on the press. This situation has influenced the interpretation of political news in pressas opposition and progoverment. The aim of study is to reveal the reflection of Democrat Party's press polıcy in Marash. In thıs article, Engizek, Demokrasiye Hizmet, Maraşın Sesi, Halk Postas1 and Kahraman Yurt newspapers examined because this newspapers give political comments and news in pages. In addition newspapaers such as Yeni Maraş, and Kurtuluş which were published during the Democrat Party were reached but the lack of copies of these newspapers prevented the evalution. In this study, newspapers that have access to copies were examined. It was concluded that Marash press had an active broadcasting life during the Democrat party period
\end{abstract}

Keywords: Marash, Local Newspapers, Democrat Party.

\section{GíRiş}

Basın toplumun yönlendirilmesinde kamuoyu oluşturulmasında en önemli araçlardan biridir. Dünya tarihi göz önüne alındığında gazetenin geçmişi oldukça eskiye uzanır. Dünya tarihindeki ilk gazetenin Louvre Müzesinde bulunan III. Ramses Dönemine ait papirüsler olduğu (MÖ. 1750'li yıllar) düşünülmektedir. Yazılı basılı niteliği taşıyan ilk gazete ise 14. yy'da Venedik'te çıkmıştır. Süreç içerisinde matbaanın Avrupa'da yaygınlaşması basın faaliyetlerinin artmasını sağlamıştır. Avrupa'da bu gelişmeler yaşanırken, matbaanın Osmanlıya gelişinin gecikmesi Anadolu'da basın faaliyetlerinin yavaş ilerlemesine neden olmuştur. Nitekim İstanbul'da çıkarılan ilk Türkçe gazete 11 Nisan 1831'de çıkarılan Takvim-i Vekayi gazetesidir. Haftalık olarak yayımlanan bu gazete devletin resmi gazetesi olarak faaliyetlerini sürdürmüştür. İlk Özel Türk gazetesi ise 21 Ekim 1860 tarihinde Şinasi ve Agâh Efendinin yayınladığı Tercüman-1 Ahvâldir (Özgen, 2018: 460-461).

İlerleyen yıllarda ülkede basın faaliyetleri yaygınlaşmış, gazeteler siyasi araç olarak da kullanılmışır. Yasama, yürütme, yargı erkleri gibi basın zamanla toplum hayatını etkileyen unsur haline gelmiştir. İktidarlar icraatlarını, propagandalarını basın aracılığıyla halka duyurmaya başlamışlardı. Türk tarihinde basın özellikle Milli Mücadele Dönemi’nde önemli bir görev ifa etmiştir. $\mathrm{Bu}$ dönemde işgalcilerin kontrolünde hareket eden İstanbul ya da 
mütareke basını ile onun karşısında var olmaya çalışan Anadolu basını bulunmaktaydı (Özkaya, 2007: 12). Basının kamuoyu oluşturmadaki, millî bilinç uyandırmadaki rolü bu süreç içerisinde iyice kendisini hissettirmiştir. Kurtuluş Savaşı'ndan sonra kendi ayakları üzerinde durmaya çalışan Türkiye Cumhuriyeti, basın konusunda bazı yaptırımlar uygulamak zorunda kalmıştır. Bunun en keskin örneklerinden biri hiç kuşku yok ki, Takrir-i Sükûn Kanunu'dur. Bu kanunla millî varlığa aykırı hareket eden birçok gazete kapatılmıştır (Turan, 2004: 223). Atatürk Dönemi'nden sonra tek parti döneminde de basına karşı belli yaptırımlar uygulanmıştır. Ancak İkinci Dünya Savaşı'nın sona ermesiyle birlikte totaliter rejimler yenilmiş; buna karşın dünya ile entegre olan rejimler ise güç kazanmıştır. Bu gelişmeler ile birlikte çok partili hayat, özgür basın, uluslararası ilişkilerde kabul görmede önemli bir unsur haline gelmiştir.

$\mathrm{Bu}$ süreçte Dünya ile entegre olmaya çalışan ve demokrasi bloğunda yer almak için gayret sarf etmeye başlayan Türkiye Cumhuriyeti, siyasi hayatta da 1946-1950 arasında hareketli bir dönem yaşamıştır. Dörtlü Takrir olarak bilinen önergenin verilmesiyle birlikte Celal Bayar, Fuat Köprülü, Adnan Menderes ve Refik Koraltan, Cumhuriyet Halk Partisi'nden (CHP) ihraç edildiler. Bu ihraçla birlikte Demokrat Parti'nin (DP) kurulması hızlanmış ve nihayet 7 Ocak 1946'da DP tarih sahnesinde yerini almıştır (Karpat, 2010: 239). DP'nin kurulmasında, muhalefetin örgütlenmesinde 1945 'te meclise getirilen Çiftçiyi Topraklandırma Kanunu'nun etkisi de unutulmamalıdır. Bu kanuna muhalif olanalar, DP çatısı altında toplanmaya başlamışı (Ekinci, 2002: 1315). DP'nin kurulması siyasi hayatın çeşitlenmesini sağladığı kadar basın üzerinde de olumlu katkı yapmıştır. 1941'de Türkiye'de günlük toplam baskı sayıları 60 bini bulan 113 gazete ile 227 dergi bulunmaktayken; bu sayı 1946 yılından itibaren ciddi şekilde bir artış göstermiştir. 1946 yılında 202 gazete ve 302 dergi yayın yapmakta olup, gazete ve dergi tirajları neredeyse yüz bine yaklaşmıştır (Koloğlu, 1992: 68-71). Demokrat Parti'nin kurulması siyasi hayatta çok sesliliği sağladığı gibi basın hayatının da çeşitlenmesine vesile oldu. Demokrat Parti kurulduğu ilk yıllarda özgür basının destekçisi olmuştur. Bu süreç gazetelerin muhalefet ve iktidar yanlısı olarak sinıflandırılmaya başlanmasına da neden olmuştur. Ankara siyasetindeki gelişmelerin basına yansımasını Maraş basınında da görmek mümkündür.

Kahramanmaraş şehri belli bir basın geçmişine sahiptir. Kahramanmaraş'ta basın faaliyetlerinin temeli Kurtuluş Savaşı yıllarına kadar inmektedir. Maraş basınında nüshası ulaşılabilen ilk yerel gazete Amal-i Milliye'dir (Zeyrek, 2012: 375). Amal-i Milliye 1920 yılında imtiyaz sahibi Hacı Nuri Bey tarafindan yayınlanmaya başlamış olup, gazete kendisini "haftada iki kez intişar eyleyen millî bir gazetedir" başlığı ile tanımlamaktaydı. Ne yazık ki, Amal-i Milliye’nin günümüze kadar ulaşabilen tek bir nüshası mevcuttur (Eliaçık, 2015: 150-151). Amal-i Milliye ile birlikte Maraş basınında mecmua tarzında yerel gazetelerin de 
olduğu bilinmektedir. Nitekim Mehmet Ali Kısakürek'in kaleme aldığ 1 Maraş Kurtuluş Harbini ateşleyen beyanname buna örnektir (Akbıyık, 2015: 131). Kahramanmaraş'ta Cumhuriyet Dönemi'nin ilk yerel gazetesi ise "Maraş"tır. Halkevinin yayın organı olarak da bilinen Maraş vilayet gazetesi, 1934-1948 yılları arasında yayınlanmıştır. Gazete yaklaşık iki yıl kadar Maraş Halkevi uhdesinde çıkmış olsa da, 1938 'de yeniden valilik tarafindan çıkarılmaya başlanmıştır (Maraş, 21.7.1938: ). Bu gazete uzun süre Maraş yerel basınının tek gazetesi olmuştur. Maraş'ta basının çeşitlenmesi ise çok partili hayata geçişle birlikte yaşanmıştır.

\section{Demokrat Parti'nin Muhalefet Yıllarında Maraş Basını (1946-1950)}

Türk Basın Tarihinde 1946-1950 arası basında yoğun rekabetin yaşandığı bir dönemdir. Bu süreçte Demokrat Parti basına karşı liberal politika takip etmiştir (Yıldız, 1996: 482). Demokrat Parti, muhalefet partisi olmasına rağmen iktidardaki CHP'yi basın özgürlügü konusunda adımlar arttırmaya sevk etmiştir. 1939'da başlayan önce bir aylık düşünülen sonra üçer aylık uzatmalarla Kasım 1947'ye kadar süren sıkıönetim uygulamalarıyla, "Basın Yayın Umum Müdürlüğü” tarafindan gazeteler üzerinde kontrol sağlanmaktaydı (Yıldız, 1996: 482). DP, bu dönemde basin özgürlügünün en büyük savunucusu olmuş ve böylece Anadolu'da basın hayatı aktif hale gelmiştir. Nitekim bu sürecin etkisiyle Maraş basınında yeni gazeteler kurulmuş böylece sadece Maraş Vilayet gazetesinden ibaret olan basın hayatı da çeşitlenmiştir. Sayıları artan bu gazeteler arasında; 1 Nisan 1947'de Doktor Kemal Tolun yönetiminde çıarılan Engizek gazetesi, Demokrat Parti İl Başkanı Selahattin Hüdayioğlu'nun çıkardığı Yeni Maraş, 19 Haziran 1950'de A. Saim Emirmahmudoğlu'nun çıkarttığı Demokrasiye Hizmet ve Ali Kiper yönetiminde çıkarılan Kahraman Yurt (Şubat 1949) ${ }^{2}$ gazeteleri sayılabilir. Demokrat Parti iktidarı döneminin ilerleyen yıllarında Maraşın Sesi ve Halk Postası gazeteleri de kurulmuştur. Maraşın Sesi gazetesi A. Yaşar Başer yönetiminde 20 Nisan 1956'da kurulmuştur (Maraşın Sesi, 20.4.1956: 1). Maraş'ta 1950'li yıllarda yayınlanan bir diğer gazete ise Halk Postası'dır. Halk Postası imtiyaz sahibi Hasan Duyar ve yazı işleri müdürü de Zeki Arifoğlu önderliğinde 12 Şubat 1954'te yayın hayatına başlamıştır (Halk Postas1,12.2.1954: 1).

DP iktidarı döneminde Maraş basınında Engizek ve Demokrasiye Hizmet gazeteleri aktif bir yayın politikası izlemişlerdir. Bu gazeteler siyasi, sosyal, kültürel birçok konuda şehre rehber olmaya çalışmışlardı. Bunda gazete

\footnotetext{
${ }^{2}$ Kahraman Yurt gazetesi 11 Şubat 1953 tarihinde dördüncü yılını bitirmiş, 12 Şubat 1953 tarihinde beşinci neşir yılına adım attığını ilanen haber yapmıştır. Bu bilgiden hareketle Kahraman Yurt gazetesinin kuruluş tarihi 12.2.1949 olmalıdır (Kahraman Yurt, 11.2.1953: 1).
} 
müdürlerinin siyasi kimlikleri de etkili olmuştur. Zira Engizek gazetesi kurucusu Dr. Kemal Tolun Millet Partisi Merkez İlçe Başkanı (Demokrasiye Hizmet, 22.7.1953:1), Demokrasiye Hizmet gazetesi kurucusu Saim Emirmahmudoğlu ise DP Merkez İlçe Başkanıdır (Demokrasiye Hizmet, 24.7.1950: 2). Bu siyasi farklılık iki gazetenin de rekabetinde etkili olmuştur. Nitekim bu rekabet adliye koridorlarına kadar yansıyacak dava süreçlerinin yaşanmasına de etki etmiştir. Kahraman Yurt gazetesi ile Maraşın Sesi gazeteleri ise keskin siyasi yorum ve haberlerden uzak durmuşlardır. Kahraman Yurt ve Maraşın Sesi gazetelerinin DP yönetimi ile ilişkilerini iyi tuttuğu yayın politikasından anlaşılmaktadır. Halk Postası ise makale ve yorumlarında DP'yi eleştiren haber ve yorumlara yer vermiştir. Çok partili hayata geçiş sürecinde ve Demokrat Parti iktidarı döneminde Maraş'ta bazı gazeteler de tespit edilmiştir. Ancak bu gazetelerin nüshalarına ulaşılamadığından, haklarındaki bilgiler diğer gazetelerde çıkan bazı haberlerden anlaşılmaktadır. Bu gazeteler arasında Yeni Maraş ve Kurtuluş gazeteleri sayılabilir. Engizek gazetesinin 12 Nisan 1947 tarihli haberinden Yeni Maraş gazetesinin, 1947 yılında DP İl Başkanı Selahhattin Hüdayioğlu tarafından haftada bir çıkarıldığı anlaşılmaktadır (Engizek, 12.4.1947: 1). Yine Engizek gazetesindeki bir haberden Kurtuluş gazetesinin de 1953 yılında yayın faaliyetinde bulunduğu anlaşılmıştır (Engizek, 8.3.1953: 1 ).

Çok partili hayata geçiş süreci ve DP iktidarı döneminde Maraş'ın en etkin gazetelerinden biri Engizek gazetesi olmuştur. Engizek gazetesi basın dünyasına neden dâhil olduğunu ilk sayısında detaylı bir şekilde izah etmiştir. Engizek gazetesi, Maraş'ın komşu iller kadar gelişmeyişinin bir iç acısı olduğunu, şehrin sevinç ve dertlerini duyurmaya çalışacağını ifade etmiştir. Nasıl ki Engizek yaylası, dağıyla, nehirleriyle bölgeye bereket saçıyor ise gazetede Engizek dağı gibi heybetli olmak için var güçle çalışacağını ilan etmiştir. Engizek gazetesi tüm okuyucularına şehrin ilerlemesi, eksiliklerin giderilmesi için yayın yapacağını duyuruyordu (Engizek, 1 Nisan 1947: 1). Engizek gazetesinde yazı işlerini fiilen idare eden Kemal Tolun'un eşi Nadire Tolun'dur. Gazete Uğur Basımevinde yayın hayatına başlamıştır. Engizek gazetesi, şikâyet ve dilekler köşesi açmak suretiyle halkın istek ve arzularının gazeteye taşınmasını sağlamıştır (Engizek, 8 Nisan 1947: 1). Engizek il ve ilçelerden dünyadan haberlerde aktararak, yerel ve uluslararası gündemi yakalamaya çalışmıştır. 1950 Haziran ayında Engizek gazetesine mukabil Demokrasiye Hizmet gazetesi yayın hayatına başladı. Gazetenin sahibi A. Saim Emirmahmudoğlu'dur. Emirmahmudoğlu Adana Muallim Mektebi'nden mezun olup erken yaşlarda şiir yazamaya başlayan edebi yönü güçlü olan bir şahsiyettir. Yaklaşık on altı yıl öğretmenlik mesleğini yerine getiren Emirmahmudoğlu, eğitimdeki tecrübesini gazeteciliğe aktarmış; Maraş basınının sürükleyici isimlerinden biri olmuştur. Emirmahmudoğlu aynı zamanda 1950'li yıllarda DP Maraş Merkez İlçe Başkanlığı görevini de yürütmüştür (Yakar, 2018: 318). Doğal olarak Emirmahmudoğlu'nun siyasi görevi, gazetede politik yorum ve haberlerin ağırlık kazanmasına etki etmiştir. 
Demokrasiye Hizmet gazetesi ilk nüshasında neden yayınlandığı konusunda uzun bir açıklama yapmamış okuyucuların gazeteyi okuyarak buna kolayca karar verebileceğini izah etmekle yetinmiștir. Fakat bir süre sonra Demokrasiye Hizmet gazetesi yayın politikasıyla ilgili açıklamalar yapan yazılar yayınlamaya başlamıştı. Bu yazılardan birisi 24 Temmuz 1950 tarihli gazetede "Muvafik mı Muhalif mi" başlığı altında çıkan bir haberdir. Gazete yaptığı bu haberinde DP'nin bir yayın organı olmadıklarını, gazetede yayınlanan yazılardan da DP'nin sorumlu olmadığını açıklamıştır. Ancak bu durumun Demokrasiye Hizmet gazetesinin demokrat olmadığı anlamına gelemeyeceği, gazetenin yazı işleri müdürü ve yazarlarının DP'nin ileri gelenlerinden oluştuğu açılaması yapılmışı (Demokrasiye Hizmet, 24.7.1950: 2). Süreç içerisinde Demokrasiye Hizmet ve Engizek gazeteleri siyasi olarak birbirlerini eleştiren haberlere yayın akışlarında yer vermeye başlamışlardı. Bu nedenle mevcut iki gazete siyasi yorum duruşları ile ilgili haberleri tekrarlayarak birbirlerini eleştiren sert yorumlar da yapmışlarıdır. Demokrasiye Hizmet gazetesi kendisini eleştiren Engizek gazetesinin Millet Partisi'nin bir parçası olduğunu, bu nedenle eleştirel haberlere yer verdiğini okuyucularına duyurmaktaydı (Demokrasiye Hizmet, 16.10.1950: 1). Buna mukabil Engizek gazetesi ise Demokrasiye Hizmet'in gerçekten DP'ye gönül vermiş kişilerden oluşmadığı yönündeki haberlerini okuyucularına aktarmaktaydı. İki gazete arasındaki bu eleştirel yaklaşım Demokrat Parti iktidarı döneminde de devam etmiştir. Şunu da vurgulamak gerekir ki; gazeteler siyasi olarak birbirlerini eleştirseler de, söz konusu Maraş şehrinin kalkınması olunca benzer hassasiyetler taşımaktaydılar. Örneğin; şehrin ağaçlandırılması, tren yolu, karayolu, sanayi kuruluşları gibi birçok konuda gazeteler şehrin kalkınması için uyarıcı haberler yapmışlardır.

\section{Demokrat Parti İktidarı Döneminde Maraş Basını (1950-1960)}

1950 Milletvekili Genel Seçimleri, Türk siyasi hayatında önemli dönüm noktalarından biridir. Bu seçimler ile DP iktidarı elde etmiş ve böylece 27 yıllık tek parti dönemi sona ermiştir. Bu değişimde tek dereceli seçim ve gizli oy, açık sayım sistemine dönülmesi de etkili olmuştur (Yücel, 2001: 37). Ayrıca Millet Partisi, Milli Kalkınma Partisi gibi partilerin de seçimde yer alması, birçok partinin seçimlerde yarıştığı bir demokratik ortamı ortaya çıkarmıştır. Seçim sürecinde gazeteler de, kendilerine yakın buldukları partilerin yanında yer almıştır (Turp, 2018: 679). DP 1950 seçiminden zaferle ayrıldıktan sonra özgür basın konusunda adımlar atmaya başlamıştır. DP'nin attığı bu adımlar, kanuni düzenlemelerle de teminat altına alınmıştır. 5680 sayılı Basın Kanunu kabul edilerek yürürlüğe konmuş, ardından matbaalar kanunu ve basın çalışanlarına yeni haklar sağlayan Basın İş Kanunu ile basın politikasındaki ılımlı hava devam etmiştir (Daşc1, 2018: 1338). 13 Haziran 1952'de 5953 sayılı "Basın meslekinde çalışanlarla çalıştıranlar arasındaki münasebetlerin tanzimi hakkında" Kanun çıartılmış ve bu kanunla gazeteciler birçok hak elde etmişlerdir. 5953 sayılı 
Kanunda; gazetecilere sendika kurma, sosyal sigortadan yararlanabilme, işverenin gazeteciyle yazılı iş anlaşması yapma zorunluluğu, gazetecinin iş akdinin feshi durumunda tazminat alması, haftalık tatil, yıllık ücretli izin gibi maddeler bulunmaktadır (Resmi Gazete, 20.06.1952, S. 8140: 3961-3964; Bulunmaz, 2012: 208). 5953 sayılı kanun, DP'nin basına karşı 1lımlı politikasının devam ettiğinin bir kanıtıdır.

Aslında ülkede yaşanan siyasi ve ekonomik gelişmeler de DP'nin bu politikasına katkı sağlamıştır. Kore Savaşı dolayısıyla tarım ürünlerine duyulan ihtiyaç, Türkiye'nin ekonomik refahını artırmıştı. Yine havaların sıcak gitmesi mahsulün bol olması gibi etkenler tarıma dayalı ekonomik değerlerde canlılık olmasına etki eden diğer unsurlardı. Bu olumlu havayla birlikte DP iktidarının ilk iki yılında traktör, biçerdöver sayısında önemli ölçüde artış yaşanmış ve ülkede tarımda ekili alanın oranında yüzde ellilik bir artış görülmüştür. Tarım alanındaki bu önemli gelişmeler diş dünyada Türkiye'ye geleceğin buğday ambarı olarak bakılmasını ortaya çıarmıştır (Yenal, 2013: 99). O yıllarda tarımın kalitesini ve verimini arttırmak için alınan tedbirler ve uygulamalar basında genişçe yer bulmuştu. Benzer bir durumu Maraş yerel basınında da görmek mümkündür. Basına karşı 1lımlı yaklaşım 1950 seçim döneminin sonuna doğru değişecektir. 1950-1954 arası dönem DP'nin ilk iktidar dönemi olmakla birlikte seçim döneminin sonuna doğru basına karşı politikanın da dönüştüğü bir süreçtir. Kore Savaşı'nın sonlanması tarım ürünlerine duyulan ihtiyacın azalmasına neden olmuştur. Tarımda makineleşme ürün artışı için olumlu olmakla birlikte kırsalda işsizliğe sebep olmuştur. Ayrıca 1954 yılındaki kuraklık, yüzde yirmi oranında ürün düşüşünü de beraberinde getirmiştir (Yenal, 2013: 104). Bu nedenle kırsaldan kentlere doğru bir göç yaşanmıştır. Ülkede tarımsal üretimin azalmasıyla birlikte ekonominin tarıma dayalı iç ve dış dengelerinin bozulması ortaya çıkmıştır (Tokgöz, 2004: 332). Ayrıca DP dışardan aldığı kredileri yol inşas1, restorasyon gibi alanlarda kullanınca üretim konusunda hükümet ekonomik değerleri yukarıya taşıyamamıştır. Siyasi başarısızlık olarak algılanan bu gelişmeler, basında eleştirel haberlerin yapılmasına neden olmuştur. Ülkede iç ve dış borçlanma artmış, 1955 'te dış borca ödenen faiz neredeyse on üç küsur milyona yaklaşmıştır (Cumhuriyet, 2.1.1955: 1).

DP basında uygulamış olduğu politikalar hakkında olumsuz haberler çıkmaya başlayınca, basının partilerinin aleyhinde yaptığı yayınlara karşı tedbirler alma yoluna gitmiştir. 1953 Temmuzuna kadar sıfat ve hizmetlerinden dolayı bakanlara yapılan hakaretin takibi şikâyete bağlıyken; bu tarihten sonra savcının, bakanın olurunu alarak resen takibine bırakılması sistemi kabul edilmiştir (Yıldız, 1996: 492). 9 Mart 1954'de toplam sekiz maddeden oluşan 6334 say1lı "neşir yoluyla veya radyo ile işlenecek bazı cürümler hakkında" bir kanun çıkarıldı (Resmi Gazete, 17.03.1954, S. 8660: 8653). Bu yasaya göre namus ve haysiyete tecavüz edilmesi, itibar kırıcı yayın yapılması, özel ve aile durumunun teşhiri, 6 
aydan 3 yıla kadar hapis ve bin liradan on bin liraya kadar para cezası verilmesi kanunlaştırıldı. Ayrıca bu suçların resmi sıfatı taşıyan birine karşı işlendiğinde ceza üçte birden yarıya kadar arttrrılacaktı. Yine bu yasa devletin siyasi ve mali itibarını sarsacak veya halkın telaş ve heyecanını arttırabilecek haberlerin yayınını bir yıldan üç yıla kadar hapis cezası, iki bin beş yüz liradan az olmamak üzere para cezası ile cezalandırıyordu. Üstelik suçlanan gazeteciye iddialarını ispat hakkı tanınmıyordu (Yıldız, 1996: 495). Doğal olarak bu durum basın özgürlügünü zedelemiştir. Gazetecilerin yayınladıkları haberden dolayı haklarında dava açılması durumunda haber konusu iddiayı ispat etme hakkı vermeyi ve ispatın davalının durumunu etkilememesini öngörüyordu. Nitekim DP Hükümetini eleştirdiği için Ulus Gazetesi başyazarı Hüseyin Cahit Yalçın, 24 Eylül 1954 tarihinde yirmi altı ay hapse mahkûm edilmiştir (Yorulmaz, 2012: 209). 1954 seçimlerinden önce çıkarılan bu kanun DP'nin 1946'da vadettiği özgür basın ilkesiyle çelişmektedir. DP her geçen gün basına karşı politikasını sertleştirerek, basına karşı liberal anlayışını terk etmeye başlamışıır.

DP'nin basına karşı tutumunun sertleşmesi Maraş’taki basının da hareketli günler geçirmesine neden olmuştur. Bu süreçte zarar görmek istemeyen gazeteler DP ile ilişkileri iyi tutma yolunu seçmişlerdi. Maraş çıkarılan gazeteler bu dönemde birbirlerini DP'ye karşı olmak ya da demokrat olmamakla eleştirmişlerdir. 1953 yılında DP'ye muhalif olan Millet Partisi'nin kapatılması (Demokrasiye Hizmet, 10.7.1953: 1), Engizek gazetesinin de DP yönelik muhalefetini azaltmıştır. Engizek gazetesi Millet Partisi çizgisinde haberler yapmaktayken bu anlayışı terk edip, DP'ye yanlısı haberlere nüshalarında yer vermeye başlamıştır. Nitekim Engizek gazetesi Başbakan Adnan Menderes'in nutuklarına yer verilmediğini gerekçe göstererek, Demokrasiye Hizmet gazetesinin yöneticilerinin partide nasıl görev aldığını sorgulamaktaydı (Engizek, 21.2.1953:1). Engizek gazetesinde aydınlık yolu gösteren yayınlarının durdurulamayacağı, gazeteyi eleştirenlerin DP'yi çıkmaza sürüklediği haber yapılarak, Emirmahmudoğlu şahsında Demokrasiye Hizmet gazetesi eleştirilmiştir (Engizek, 4.3.1953: 1). Engizek gazetesi şahsi çıkar güdenlerin DP il yönetimine sızdı̆ıın haber yapmakta, köşe yazarlarından $\mathrm{M}$. Cebe de bu konu üzerinde yazılar yazmaktaydı. Cebe yazısında Engizek yazı işleri müdürü Nadire Tolun'un DP'nin Fevzipaşa Mahallesi teşkilatına üye olduğunu, DP il yönetiminin bundan haberdar olması gerektiğini yazmaktaydı (Engizek,2.3.1953: 1). Engizek, DP'nin selameti için ilçe başkanının ihraç edilmesi gerektiğini, DP'nin huzuru için bunun şart olduğunu vurgulanmaktaydı (Engizek, 4.3.1953: 1).

Bu haberlere Demokrasiye Hizmet' in cevabı da aynı sertlikte olmuştur. Ancak Engizek yazı işleri müdürü Nadire Tolun Ankara'ya DP genel merkezine giderek bir dizi görüşmeler yapmış ve bu görüşmelerin neticesini gazetesinde yayınlamıştır. Nadire Tolun'un yaptığı bu görüşmelerinden gazetede 
okuyucularına aktardığı önemli hususlar ise Demokrasiye Hizmet'in, Demokrat Parti'nin yayın organı olmadığı, DP'nin tek gazetesinin Zafer gazetesi olduğu ve herhangi bir gazetecinin de özel imtiyaza sahip olmadığı konularıydı (Engizek, 23.3.1953: 1). Nadire Tolun'un yazısında bahsettiği Zafer gazetesi 30 Nisan 1949 'da yayın hayatına başlamıştı. Zafer gazetesi yayın hayatı boyunca (19491960) DP'nin yarı resmi gazetesi gibi hareket ederek partinin sözcülüğ̈̈nü yapmıştır (Öztürk, 2007: 1). Zafer gazetesi ilk nüshasında şahsi menfaat ve mevki peşinde koşanlara karşı yalnızca millî menfaatleri savunacağını ilan ederken, ülkenin kötü gidişatından CHP iktidarını sorumlu tutmuştu. Ayrıca Zafer gazetesinde ülkenin bu kötü durumundan kurtulması için ise tek çarenin DP kadroları olacağ iddia edilmiştir (Zafer, 30.4.1949: 1).

Ulusal basında Zafer gazetesi karşısında ise Ulus gazetesi ${ }^{3}$ ve Cumhuriyet gazeteleri bulunmaktaydı. Benzer bir durum Maraş basını içinde geçerlidir. Demokrasiye Hizmet gazetesi DP yanlısı haberler yaparken, Halk Postas1 gazetesi CHP yanlısı yorum ve haberleri nüshalarına taşımıştır. Engizek gazetesi ise başlangıçta DP'ye karşı muhalif yönde haberler yaparken daha sonralarını eleştirilerini Emirmahmudoğlu ve Demokrasiye Hizmet gazetesine yöneltmiştir. Kahraman Yurt ve Maraşın Sesi gazeteleri ise DP Hükümetleri döneminde iktidarı eleştiren haber ve yorumlara nüshalarında yer vermemiştir. Gazeteler partilerden istifa eden ya da partilere katılım haberlerinde kendi yorumları çerçevesinde yayınlamışlar. Maraş basınında bucak, köy ve kazalardan partilere katılım ve istifaların ayrıntılı şekilde haberleştirildiği görülmüştür. Halk Postası, Elbistanda Cela Köyü Muhtarı Bayram Yetişkin'in DP'den istifa ettiğini ilan etmekteydi. Böylece "Cela Köyü DP teşkilatı felce uğramıştı"” yorumu yapılmıştı (Halk Postası, 17.1.1957: 1). Bu haber Demokrasiye Hizmette yer almamıştır. Buna mukabil Demokrasiye Hizmet "Halk Partililerin yeni bir marifeti” başlığıyla Kemallı Köyü’nden Abdullah Ardıç'ın kendi iradesi dışında Halk Partisi'nin ismini parti teşkilatına kaydettiğini, sonradan ismini sildirdiğini belirterek yine de gazeteden Halk Partisi ile hiçbir bağı olmadığını ilan etmekteydi (Demokrasiye Hizmet, 12.1.1957: 1). Gazeteler bu türden haberleri yakın durdukları siyasi partilere göre yayınlamaktaydı. Bu türden haberin veriliş şekli gazetelerin siyasi duruşunu yansıtmaktaydı. Nitekim Demokrasiye Hizmet, DP lehinde yayın yaptığı için muhalif yönde yayın yapan medyanın eleştiri ve yorumlarına muhatap olmuştur.

Engizek gazetesi ve parti içi muhalefete maruz kalan Emirmahmudoğlu, Demokrasiye Hizmet gazetesi aracılığıyla haklılığını ortaya koyan yayınlar

\footnotetext{
${ }^{3}$ Hâkimiyeti Milliye Gazetesi 1934’ten itibaren Ulus gazetesi adını almıştır. Gazete CHP'nin benimsemiş olduğu ideolojinin toplumda yaygınlaştırılması ve içselleştirilmesi görevini görmüştür. 1950 seçimlerinde CHP'nin iktidarı kaybetmesiyle birlikte Ulus gazetesi de DP yönetimine karşı muhalefetin sesi olmuştur ( Öztürk, 2007: 84).
} 
yapmaya çalışmıştır. Emirmahmudoğlu eleştirilere maruz kalmasına rağmen, DP Merkez Haysiyet Divanı tarafından aklanmış olup görevine devam etmiştir (Demokrasiye Hizmet, 6.3.1951: 1). Emirmahmudoğlu, Engizek gazetesinin yayın politikasını jurnalciliğin acemi bir örneği olarak tarif etmekteydi (Demokrasiye Hizmet, 20.2.1953). Kahraman Yurt gazetesi de bu süreçte Emirmahmudoğlu'na destek olmuştur. Kahraman Yurt gazetesi Emirmahmudoğlu'nun grip olup hastalanmasını bile haber yaparak, geçmiş olsun dileklerini gazeteye taşımaktaydı. Ayrıca Kahraman Yurt gazetesi Emirmahmudoğlu'nun hakkında çıkan haberlere karşı tekzip haberlerine sayfalarında yer vermekteydi (Kahraman Yurt, 2.2.1953: 1). Zira Kahraman Yurt gazetesi sahibi Ali Kiper ayn zamanda Demokrasiye Hizmet gazetesinin Neşriyat Müdürlügünü de yürütmekteydi. Bu nedenle Ali Kiper Demokrasiye Hizmetin yanında yer alarak, Engizek gazetesi hakkında muhtelif ithamlarda da bulunabilmekteydi (Engizek 1.9.1955: 1). Maraş basınında gazeteler birbirlerine eleştirilerini sıralarken, DP yönetimine karşı direk eleştirel yorumlardan kaçınmışlardır. Eleştiriler gazete idarecilerinin şahısları üzerinden yapılmıştır.

DP 1954 Milletvekili Genel Seçimlerinden zaferle çıkmıştı. Fakat seçim sonuçları DP'nin basına karşı politikasını yumuşatmamış aksine daha da keskinleşmesine neden olmuştur. 1954 seçimlerinde DP Kırşehir'den vekil çıkaramayınca bu ili Nevşehir'e bağlamıştır. Kırşehir vekili CMP genel başkanı Osman Bölükbaşı yaptığ konmuştu (Şavkılı 2018: 210). Bu durum Halk Postası Yazı İşleri Müdürü Zeki Arifoğlu tarafından eleştiriye tabi tutulmuştu. Arifoğlu yazısında Kırşehir'i kaza yapmanın makul bir izahı olmadığını, seçim sonuçları nedeniyle böyle bir tasarrufta bulunulmasını ise "demokrasinin başındaki demokrasi kulıcl" olarak tanımlamıştır (Halk Postası, 7.6.1954: 1). DP icraatlarıyla ilgili olarak yapılan eleştirilere karşı tahammülsüz ve sert tepkiler ortaya koymuştur. Bu durum basın üzerinde de uygulanmıştır. DP Hükümeti gazetelerin baskı sayısı ve ikinci baskılarını kontrol etmekteydi (Koç, 2010: 207). Ayrıca 1956 yılında basın kanunda değişiklik yapılarak cevap ve düzeltme hakkı, tekzip hususunda düzenlemeye gidilmiştir. Düzenleme ile tekzip kontrolü ve yayına izin verilmesi savcıların denetimine bırakılmıştır. Turan Güneş mecliste yaptığı konuşmada bu durumu eleştirerek savcıların hükümetin memuru olduğu dolayısıyla tekzip ya da cevap hakkının hükümetinin lehine işleyeceği eleştirisini yapmıştır (Kubilay, 2104: 192-199). $\mathrm{Bu}$ kanunun Maraş basınında uygulamaları sıklıkla görülmektedir. Özellikle Engizek ve Demokrasiye hizmet kendi sayfalarında birbirleri aleyhindeki tekzip ilanlarına yer vermek zorunda kalmışlardır.

Demokrat Partinin basını kontrol araçlarından biride resmi ilanlar yolu ile gerçekleşmekteydi. O yıllarda gazetelerin satış rakamları ile ayakta kalması oldukça zordu. Dolayısıyla resmi ilanlar gazeteler için ciddi gelir anlamına geliyordu. Resmi ilanların gazetelere dağıtımı bakanlığın takdirine bırakılmıştır. 
Bakanlıkta gazeteleri lehte ve aleyhte yayın yapan olarak sınıflandırıp resmi ilanların dağıtımında eşitlik ilkesine uymuyordu (Yıldız, 1996: 497). Bu konuda 1953 ve 1957 'de kanunlar çıkarılsa da eşitlik ilkesine dikkat edilmediği anlaşılmaktadır. 1950 ile 1959 yılları arasında Zafer gazetesi 7.114.330 TL reklam alırken; Hürriyet, Milliyet, Son Havadis gibi dönemin diğer gazeteleri bu rakamın çok gerisinde kalmışlardır (Alemdar, 1996: 136). Dolayısıyla Zafer gazetesi resmi ilan ya da reklam almada diğer gazetelere göre daha rahat hareket edebilmiştir.

1957 seçimleri DP'nin girdiği son seçimdir. DP önceki seçime göre oy kaybederek de olsa \%47 oy alarak seçimden zaferle çıkmıştır (Kili, 2001: 257). Ancak DP'nin bir önceki seçime göre oyları azalmıştır. DP 23 vilayette seçimi kaybetmiştir; Bu vilayetlerden biri de Maraş'tır (Şavkı1lı, 2017: 493). Ekonomik düzensizlik, dış borçların ödenememesi ve Türk lirasının değer kaybetmesi gibi nedenler DP'nin oy kaybının başlıca nedenleri olarak gösterilebilir. Ekonomik gerileme bazı olaylarda gözlemlenebilir bir hal almıştır. 6/7 Eylül olaylarında Kıbrıs sorunu ve Rumlara şüpheyle bakılmasının etkisi olsa da İstanbul'daki işsiz ve yoksul insanların yağma faaliyetleri ekonomik göstergelerin iyi olmadığının bir işaretidir. DP bu olayların büyümesinde basını ve muhalefet partilerini sorumlu tutmaktadır. Nitekim Adnan Menderesin bu konudaki görüşlerini içeren mülakatı Maraşın Sesi gazetesinde yer almıştı. Adnan Menderes havaların kurak gitmesi, Amerikan iktisadi yardımının alınamaması, 6/7 Eylül olaylarının istismar edilmesinde muhalefet partilerinin ve basının halkı olumsuz yönde etkilediklerini ifade etmiştir (Maraşın Sesi, 2.3.1957: 1). Bu bakış açısı DP'nin basına karşı uyguladığı politikaların sertleşmesine de etki etmiştir. Şunu da vurgulamak gerekir ki, 6/7 Eylül olayları Maraş basınında devlet ciddiyetiyle ele alınmıştı. Yapılan yayınların halkı kışkırtmaktan uzak olması gayet güzel bir basın sorumluluğu örneği olarak değerlendirilebilir.

6/7 Eylül olaylarına Maraş basınında en az yer veren gazete Demokrasiye Hizmet gazetesidir. Demokrasiye Hizmet "TBMM Meclisi toplantıya çağırdı başlığı" altında Cumhurbaşkanının Kıbrıs meselesi ve üç şehirde çıkan olaylarda fevkalade hal (olağanüstü hal) ilan edilmesiyle ilgili TBMM'yi toplantıya çağırdığı haberi yapılmıştı (Demokrasiye Hizmet, 8.9.1955: 1). Bu haber dışında Demokrasiye Hizmet'te 6/7 Eylül olaylar1 ile ilgili herhangi bir haber ya da yorum yapılmamıştır. Demokrasiye Hizmet' in bu olaylara çok az yer vermesi DP Hükümetini koruma kaygısından olsa gerektir. Zira Emirmahmudoğlu DP'de aktif siyaset yapmaktadır. Buna mukabil diğer yerel gazeteler olayı detaylı şekilde okuyucularına duyurmuşlardır. Engizek gazetesi 6/7 Eylül olaylarını en teferruatlı şekilde anlatan gazetedir. Olayların nasıl başladığı, İstanbul ve İzmir'deki yankılarını detaylı şekilde okuyucuya aktarılmışıı (Engizek,7.9.1955: 1). Gazete İstanbul'da halk1 galeyana getirip yağma faaliyetlerine katılan 2057 kişinin yakalandığ 1 ve bu kişilerin Selimiye Kışlası'nda tutulduğu haberini 
okuyucularına duyurmuştur (Engizek, 8.9.1955: 1). Ayrıca Engizek gazetesi, Sik1 Yönetim İdaresi tarafindan Divanı-1 Harp mahkemelerinin kurulduğunu bu doğrultudaki soruşturma detaylarını sayfalarına taşımıştı (Engizek, 9.9.1955: 1). Kahraman Yurt gazetesi de 6/7 Eylül olaylarını detaylı şekilde okuyucularına aktarmış, olayların Edebi Şef Atatürk'ün doğduğu ev ile Selanik Konsolosluğu'muzda bombalar patlatılması ile patlak verdiğini izah etmiştir (Kahraman Yurt, 7.9.1955: 1). Kahraman Yurt olaylarla ilgili “Türk'ün asaleti başlığı” altında imzasız bir makale yayınladı. Yazıda Yunanistan'la dostluğun bozulmasından Rumların tahrikleri ve Kıbrıs Rum Kilisesi Papazı Makarios'un etkili olduğu vurgulanmıştı. Ayrıca menfur saldırının affedilemeyeceği, Türk'ün asaletinin atasına gösterdiği hürmet hissinden olduğu vurgulanmış, iki memleket arasındaki dostluğun devam etmesi ve acı olayların unutulması temennisinde bulunulmuştur. Halk Postası'da 6/7 Eylül olaylarında Hükümetin Tebliğini yayınlamıştır. Tebliğde Atatürk'ün evine ve konsolosluğa yapılan saldırının halkta infiale yol açtığı bu durumdan yararlanan bazı tahrikçilerin yağma faaliyetlerinde bulunduğu izah edilerek, olayları başlatanların cezalandırılacağ 1 ve Hükümetin bu konuda desteklenmesi istenmekteydi. Halk Postası bu tebliği yayınlamasına rağmen DP'ye karşı eleştirel haberleri sayfasına taşımıştır. Tebliğden iki gün sonra "Sürmene'de üç genel meclis üyesi istifa etti" başlı̆g altında DP içinde gizliden gizliye çözülme devam ediyor yorumu yapılarak, Sürmene ilçesindeki DP idare kurulunun toptan istifası haber yapılmıştı (Halk Postas1, 12.9.1955: 1). Maraş basınında 6/7 Eylül olaylarının aktarılma şekli gazetelerin de siyasi duruşlarının adeta bir yansımasıydı.

DP, ulusal ve yerel basında çıkan haberleri yakından takip ediyor ve bu konuda belli tasarruflarda bulunuyordu. Aleyhte haber yapan gazete ya da gazeteciler hakkında davalar açılmaktaydı. DP'nin son seçim döneminde 195760 arasında 2300 basın davası sonuçlandırılarak, 257 gazeteci hapse mahkûm edilmiştir. Yakup Kadri Karaosmanoğlu, Tahir Belek gibi ünlü kimseler dahi tutuklanan gazeteciler arasındaydı (Koç, 2010: 208). Ayrıca 26 Kasım 1957'de çıkarılan bir kararname ile gazete ve dergilerin ihtiyacı olan kâğıtların tek elden ithali zorunluluğu getirilmişti (Yorulmaz, 2012: 209). Bu durum basın üzerindeki kontrolü daha da kolaylaştırmıştır. Kontrol yalnızca neşir alanında değil radyo yayınları üzerinde de gerçekleşmekteydi. Muhalefete radyo yayınlarında yer verilmeyince bir grup muhalif radyo dinlemeyenler cemiyeti kurmuştur (Koç, 2010:209). Resmi ilanların dağıtımı, kâğıdın tek elden ithali, DP'nin basını kontrolünü kolaylaştırmıştır. Bu süreçte Maraş yerel basınında DP'ye yakın olan gazeteler daha rahat hareket etmekteydiler. Genellikle gazeteler yayınlarında DP'yi direk eleştiren yorumlardan uzak durmuşlardı. Nitekim Halk Postası gazetesi kâğıt konusundaki kısıtlamayı sayfasına taşımış ve gazetelerin ikinci baskı yapması yasaklanmıştır şeklinde yorumlayarak okuyucularına duyurmuştur (Halk Postas1, 16.1.1957: 1). 
Maraş yerel basınında DP'nin yayın organı gibi düşünülen Demokrasiye Hizmet gazetesinin diğer gazetelerden daha fazla resmi ilan geliri elde ettiği muhtemeldir. Zira DP iktidarı döneminde Emirmahmudoğlu'nun gazetesinde resmi ilan konusunda mağdur edildiğine dair herhangi bir haber yaptığ 1 görülmemiştir. Diğer taraftan Engizek gazetesinin de resmi ilan konusunda mağduriyet yaşadığı tespit edilmemiştir. Ancak şehrin diğer bir gazetesi Maraşın Sesi gazetesi resmi ilan konusunda bazı eleştirileri sayfalarına taşımışıı. Maraşın Sesi gazetesi resmi ilan ya da siyasi konularda üstü kapalı ifadeler kullanırken; darbeden sonra bu eleştiriler daha keskin şekilde gazetede yer almıştır. Maraşın Sesi gazetesi, Engizek gazetesi yazı işleri müdürü Nadire Tolun'u "Başvekil hain Menderes'in iltifat mektubuna mazhar olan Lüks Nadire Tolun" diye tanımlayarak, Engizek gazetesinin resmi ilanlarla beslendiği iddialarını sayfalarına taşımışırı (Maraşın Sesi,17.8.1960). Maraş'ın Sesi gazetesi bu türden haberlerle Engizek gazetesinin resmi ilan konusunda kayırıldığını iddia etmekteydi. Bu tür haberler verilirken kullanılan üslup haber yapmanın ötesinde gazetenin şahsi hesaplaşmalarda kullanıldığı izlenimini doğurmaktadır. Dönemin gazetecileri arasında gazeteler aracilığıla hakaretler mahkeme salonlarına da taşınmıştır. Demokrasiye Hizmet gazetesi sahibi Saim Emirmahmudoğlu, Engizek gazetesi sahibine hakaret ettiği gerekçesi ile 250 lira ağır para cezasına çarptırılmıştır (Maraşın Sesi, 11.6.1960).

Gazeteler arası rekabet, siyasi olayları yorumlama biçimi gazeteciler arasındaki gerginliğin başlıca nedeni olarak görülebilir. 1960 Darbesinden sonra Maraş basını için dengeler değişecektir. Maraş basınında yeni gazeteler kurulmuş olsa da, gazeteler üzerindeki kontrol ve resmi ilan vermedeki tasarrufların gazeteleri mağdur ettiği anlaşılmaktadır. DP'nin iktidarı kaybetmesinin akabinde Demokrasiye Hizmet gazetesinin mağdur edildiği anlaşılmaktadır. Demokrasiye Hizmet, ihtilalden sonraki süreçte yaşadığı mağduriyeti tablo halinde sayfalarına taşınmışıtır. Bu durum DP dönemi için de bir fikir verebilecek mahiyettedir. İhtilal sonrası Maraş basının da gazete sayısı artmış fakat resmi ilan dağıtımında keyfilik DP dönemindekine benzediği anlaşılmaktadır. Resmi ilanların gazete gelirlerinin önemli bir kalemi olduğundan bu konuda fikir vermesi nedeniyle Demokrasiye Hizmet'in 1963 yılında yaşadığı mağduriyet Ocak, Şubat, Mart ayı resmi ilan tablosu aşağıda ifade edilmiştir:

Tablo 1: 31 0cak-Mart Resmi İlan Dağıtımı (Demokrasiye Hizmet, 18.7.196320.7.1963)

\begin{tabular}{|l|l|l|l|l|l|l|l|l|l|l|}
\hline & \multicolumn{3}{|c|}{$\begin{array}{c}\text { Dağıtılması } \\
\text { Gereken İlan }\end{array}$} & \multicolumn{2}{|c|}{ Dağıtılan İlan } & \multicolumn{4}{c|}{ Eksiği } \\
\cline { 2 - 8 } & $\begin{array}{l}\text { Oc } \\
\text { ak }\end{array}$ & Şubat & Mart & $\begin{array}{l}\text { Oc } \\
\text { ak }\end{array}$ & $\begin{array}{l}\text { Şub } \\
\text { at }\end{array}$ & $\begin{array}{l}\text { Ma } \\
\text { rt }\end{array}$ & $\begin{array}{l}\text { Oc } \\
\text { ak }\end{array}$ & Şubat & Mart & $\begin{array}{l}\text { Topl } \\
\text { am }\end{array}$ \\
\hline
\end{tabular}




\begin{tabular}{|l|l|l|l|l|l|l|l|l|l|l|}
\hline $\begin{array}{l}\text { D. } \\
\text { Hizm } \\
\text { et }\end{array}$ & 514 & $\begin{array}{l}1220, \\
70\end{array}$ & $\begin{array}{l}253 \\
0.7\end{array}$ & $\cdots$ & $\begin{array}{l}101 \\
0\end{array}$ & $\begin{array}{l}83 \\
0\end{array}$ & 514 & $\begin{array}{l}210,7 \\
0\end{array}$ & $\begin{array}{l}1700 . \\
70\end{array}$ & $\begin{array}{l}2425 . \\
4\end{array}$ \\
\hline $\begin{array}{l}\text { Engiz } \\
\text { ek }\end{array}$ & 632 & $\begin{array}{l}1138, \\
70\end{array}$ & $\begin{array}{l}345 \\
8.7\end{array}$ & 200 & $\begin{array}{l}108 \\
0\end{array}$ & $\begin{array}{l}68 \\
30\end{array}$ & 432 & $\begin{array}{l}1138, \\
70\end{array}$ & & $\begin{array}{l}1550, \\
7\end{array}$ \\
\hline $\begin{array}{l}\text { H. } \\
\text { Posta } \\
\text { s1 }\end{array}$ & 270 & $\begin{array}{l}746,7 \\
198\end{array}$ & 230 & $\begin{array}{l}220 \\
6.7\end{array}$ & $\begin{array}{l}22 \\
0\end{array}$ & 40 & & & \\
\hline $\begin{array}{l}\text { K. } \\
\text { Yurt }\end{array}$ & $\cdots$ & $\begin{array}{l}368,6 \\
0\end{array}$ & $\begin{array}{l}138 \\
8.6\end{array}$ & ---- & 640 & 64 & & & $\begin{array}{l}748.6 \\
0\end{array}$ & $\begin{array}{l}748,6 \\
0\end{array}$ \\
\hline $\begin{array}{l}\text { M. } \\
\text { Sesi }\end{array}$ & $\cdots$ & 53,60 & $\begin{array}{l}164 \\
3.6\end{array}$ & $\begin{array}{l}---- \\
-\end{array}$ & 900 & $\begin{array}{l}90 \\
0\end{array}$ & & & $\begin{array}{l}743.6 \\
0\end{array}$ & $\begin{array}{l}743,6 \\
0\end{array}$ \\
\hline $\begin{array}{l}\text { Gerç } \\
\text { ek }\end{array}$ & 85 & $\begin{array}{l}711,7 \\
0\end{array}$ & $\begin{array}{l}291 \\
1.7\end{array}$ & 80 & $\begin{array}{l}252 \\
0\end{array}$ & $\begin{array}{l}25 \\
20\end{array}$ & 5 & $\begin{array}{l}519,7 \\
0\end{array}$ & $\begin{array}{l}391.7 \\
0\end{array}$ & 916,4 \\
\hline
\end{tabular}

Tablolardan anlaşılacağı üzere resmi ilanlarda Engizek ve Demokrasiye Hizmet gazeteleri hak ettikleri ilanları alamadığı gibi ciddi ekonomik kayıp yaşamışlardır. Bu mağduriyet sonrası ayakta kalmaya çalışan Engizek ve Demokrasiye Hizmet gazeteleri, yayınlarına son vererek birleşmek zorunda kalmıştır. Böylece DP Dönemi'nin Maraş basınındaki iki önemli gazetesi bağımsız olarak gerçekleştirdikleri yayın sürecini de sonlandırmış oldular. Bu iki gazete birleşme kararı aldıktan sonra yayın faaliyetlerine "Memleket gazetesi" adıyla devam ettiler. Tablodan çıkarılacak bir diğer sonuçta darbeden sonra Maraş basınında resmi ilan konusunda büyük mağduriyet yaşamayan tek gazetenin Halk Postası gazetesi olduğu gerçeğidir. Halk Postası, DP iktidarı boyunca muhalif yayın yapmış ve CHP politikalarını desteklemişti. Halk Postası gazetesinin DP karşısında olması muhtemeldir ki darbe sonrasında resmi reklam alımında avantaj elde etmesine kolaylık sağlamıştır.

Ülkede ekonomik değerlerin istenilen seviyeye gelmemesi, kuyrukların oluşmasına ve sosyo-ekonomik yapının bozulmasına etki etmeye başlamıştı. $\mathrm{Bu}$ sürece karşı DP, otoritesini koruyarak yol alamaya çalışmıştır. Basına karşı sık1 tedbirler alınmış muhalif görülen bürokrat ve asker sınıfı görevden uzaklaştırılmıştır. İnönü'ye bağlı komutanlar emekli edilmiştir. Muhalif kesim, görevinde devam eden bürokratları DP'ye bağlı olan makam mevki için hareket eden kişiler olarak görmekteydi. Ordudaki genç subaylar da komutanlarının emekliye sevk edilmesinden rahatsız olmuşlardı. Artan hayat pahalılığına denk maaş alınamaması, toplum içindeki gelir dağılımındaki eşitsizlik gibi nedenler genç subayları harekete geçirmiş ve 27 Mayıs darbesi örgütlenmiştir (EkincikliŞahin, 2018: 41). Ne yazık ki; darbe yapan grubun başarılı olmasıyla DP'nin iktidarı sona ermiştir. Bu olay aynı zamanda Türkiye Cumhuriyeti'nde darbeler tarihinin de başlangıcı olarak kabul edilmektedir. Türk siyasi hayatına kara bir 
leke olarak geçen bu olay, Yassıada Mahkemeleri ile daha da trajik bir hal almıştır. Yassıada mahkeme tutanaklarında birçok detay da ortaya çıkmıştır. Nitekim DP'nin bazı basın organlarına örtülü ödenekten yardım ettiği ortaya konmuştur (Çakır ve Yavalar, 2017: 269). DP yaklaşık on yıllık iktidarı döneminde elbette birçok olumlu veya olumsuz faaliyetlere imza atmıştır. Ancak demokratik olgunluk seçimle gelen iktidarın seçimle görevini bırakmasını gerektirir. Türk demokrasi tarihi açısından DP'nin darbe ile iktidardan uzaklaştırılması, siyasi hayatımızda demokrasiye ve millî iradeye indirilmiş bir darbedir.

\section{Sonuç}

DP'nin kurulması ve akabindeki on yıllık iktidarı Maraş'ta basın hayatına olumlu etki etmiştir. Nitekim DP muhalefet partisi olarak hizmet etmeye çalıştı̆̆ süreçte basın özgürlüğü konusunda ciddi adımlar atılmasını sağlamıştır. $\mathrm{Bu}$ süreçte Engizek, Demokrasiye Hizmet, Kahraman Yurt, Yeni Maraş, Halk Postası gibi gazeteler yayın hayatına başlamıştır. DP, iktidarın altın yılları diyebileceğimiz 1950-1954 döneminde, basın özgürlüğü için olumlu adımlar atsa da; seçim döneminin sonuna doğru basına karşı olan liberal politikalarını terk etmeye başlamıştır. Basına karşı uygulanan bu politika DP'nin iktidarının son bulmasına kadar devam etmiştir. DP'nin siyasetini Maraş basınında da gözlemlemek mümkündür. Zira Demokrasiye Hizmet, Kahraman Yurt, Yeni Maraş gazeteleri DP ile iyi ilişkiler kuran ve yayın hayatını sürdüren gazetelerdir. Kahraman Yurt ve Yeni Maraş gazeteleri ülke ve dünya siyaseti ile ilgili haberleri aktarmada dönemin diğer gazetelerine göre daha yüzeysel kalmışlardır. Halk Postas1 ve Engizek gazetelerini ise bu gazetelerden ayr1 tutmak gerekir. $\mathrm{Bu}$ gazeteler DP iktidarına karşı muhalif nitelikte yayın yapmışlardır. Engizek gazetesinin muhalif kimliği süreç içerisinde kırılsa da, Halk Postasının muhalif özelliği daha keskindir.

Halk Postası yayın hayatı boyunca DP iktidarına muhalif kalmış ve daha çok CHP'ye yönelik olumlu haberleri nüshalarına taşımıştır. Şunu da vurgulamak gerekir ki, diğer gazetelerin DP iktidarına her konuda tam destek verdiği de söylenemez. Gazetelerde özellikle yerel bazda şehrin beklentileri, şehrin eksik yönleri dile getirilerek, DP yetkililerinin dikkati çekmeye çalışmıştır. Nitekim Demokrasiye Hizmet gazetesi sahibi Emirmahmudoğlu, Demokrasiye Hizmet' in halkın emrinde olduğunu, şehrin eksikliklerini dile getireceklerini, ikaz ve tenkitlerle şehrimizi daha güzelleştirme emelinde olduklarını belirtmiştir (Demokrasiye Hizmet, 17.7.1950: 1). Aslında bu düşünce Demokrasiye Hizmet ve Engizek gazetelerini birbirine yaklaştırmıştır. Engizek gazetesi de, DP ye karş1 muhalif kimliğine rağmen süreç içerisinde Demokrasiye Hizmet gazetesiyle birleşmiştir. Yayınlarından anladığımız kadarıyla Engizek ve Demokrasiye Hizmet'in kurucuları Maraş sevdalısıdır. Bu şahıslar Maraş sevdasını her türlü 
fikri ayrılı̆̆ın üstünde tutmaktaydılar. Demokrat Parti iktidarı sonrası 1963 yılında "Maraş Maraşlılarındır" düsturuyla hareket edip, şehri geliştirmek adına Engizek ve Demokrasiye Hizmet gazeteleri güçlerini birleştirmişlerdi.

Demokrat Parti Dönemi'nde basın alanında edinilen tecrübe ileriki yıllarda Kahramanmaraş'ta aktif bir gazetecilik hayatı yaşanmasına etki etmiştir. DP iktidarı akabinde gerçekleşen darbe ile siyasetin dizayn edilmesi, gazeteciler arasında kırgınlıklara yol açmıştır. Hızlı değişen siyasi süreç gazete sahiplerinin birbirlerini eleştirmeleri, gazeteler üzerinden yaşanan şahsi çekişmelere neden olmuştur. Yine de Demokrat Parti Dönemi'nde Maraş basını oldukça aktif yayın hayatına sahne olmuştur. Gazeteler Maraş'ın kalkınması konusunda fikir birliği etmiş̧̧esine şehrin gelişmesine katkı sunmaya çalışmışlardır.

\section{KAYNAKLAR}

\section{Resmi Yayınlar}

Resmi Gazete, Say1: 8140, 20.06.1952.

Resmi Gazete, Say1: 8660, 17.03.1954.

\section{Araştırma-İnceleme Eserler}

Akbıyık, Yaşar (2015), Milli Mücadelede Güney Cephesi Maraş, Atatürk Araştırma Merkezi Yayınları, Ankara.

Alemdar, Korkmaz (1996), İletişim ve Tarih, İmge Kitabevi, Ankara.

Bulunmaz, Barış (2012), "Türk Basın Tarihi İçinde Demokrat Parti Dönemi ve Sansür Uygulamaları”, Öneri Dergisi, C. 10, S. 37, İstanbul, ss. 203212.

Çakır, Hamza ve Yavalar, Elif (2017), "Demokrat Parti İktidarı ve Basın", Manas Sosyal Araştırmalar Dergisi, C. 6, S. 3, ss. 257-270.

Daşcı, Elif (2018), "Darbe Sonrası Karikatürlerde Menderes ve Demokrat Parti İmajı”, Türk Basın Tarihi, II. Cilt, Atatürk Araştırma Merkezi Yayınları, Ankara, ss. 1335-1358.

Ekinci, Necdet (2002), “İnönü Dönemi ve II. Dünya Savaşı Yılları”, Türkler, C. 16, Yeni Türkiye Yayınları, Ankara.

Ekincikli, Mustafa ve Şahin, Alparslan (2018), "27 Mayıs Askeri Darbesi Öncesinde Kurulan 'İhtilal Örgütleri' ve Dokuz Subay Olayı", Akademik Bakış Dergisi, S. 70, Kasım-Aralık, ss. 39-58. 
Eliaçı,, Muhittin (2015), "Amali Milliye Gazetesinde Maraş ve Milli Mücadeleye Dair Ayrıntılar”, Milli Mücadelede Güney Cephesi Sempozyumu, Atatürk Araştırma Merkezi Yayınları, Ankara, ss. 150-151.

Karpat, Kemal (2010), Türk Demokrasi Tarihi, Timaş Yayınları, İstanbul.

Kili, Suna (2001), Türk Devrim Tarihi, Türkiye İş Bankası Yayınları, İstanbul.

Koç, Rasim (2010), İdam Sehpasındaki Dış İşleri Bakanı Fatin Rüştü Zorlu, Ötüken Yayınları, İstanbul.

Koloğlu, Orhan (1992), Osmanlıdan Günümüze Türkiye'de Basın, Cep Üniversitesi-İletişim Yayınları, İstanbul.

Kubilay, Çağla (2014), "Demokrat Parti Döneminde Bir Baskı ve Denetim Mekanizması Olarak Cevap ve Düzeltme Hakkının Kullanımı: Ulus Örneği (1950-1960)", Dumlupınar Üniversitesi Sosyal Bilimler Dergisi, S. 39, Kütahya, ss. 187-201.

Özgen, Arif (2018), “Gazete”, Kahramanmaraş Ansiklopedisi, C. 3, Kahramanmaraş Sütçü İmam Üniversitesi Yayını, No: 145, Kahramanmaraş, ss. 460-465.

Özkaya, Yücel (2007), Milli Mücadele'de Atatürk ve Basın (1919-1921), Atatürk Araştırma Merkezi Yayını, Ankara.

Öztürk, Onur (2007), Demokrat Parti Döneminde Basın Rejimi Ve Zafer Gazetesi (1957-1960) Ulus Gazetesi İle Karşılaştırmalı Bir İnceleme, Ankara Üniversitesi Sosyal Bilimler Enstitüsü Gazetecilik Ana Bilim Dalı Basılmamış Yüksek Lisans Tezi, Ankara.

Şavkılı, Cengiz (2018), "Demokrat Parti İktidarının Son Yılında Başbakan Adnan Menderes'in Adana, Mersin, Maraş ve Hatay Ziyaretleri”, Türk Dünyası Araştırmaları Dergisi, C. 119, S. 235, İstanbul, ss. 205-232.

Şavkıl1, Cengiz (2017), "Maraş Yerel Basınında 1957 Seçimleri ve Siyasi Partiler”, Kahramanmaraş Sütçü İmam Üniversitesi Sosyal Bilimler Dergisi, C. 14, S. 2, Kahramanmaraş, ss. 477-500.

Tokgöz, Erdinç (2004), Cumhuriyet Döneminde Ekonomik Gelişmeler, Türkiye Cumhuriyeti Tarihi II, Atatürk Araştırma Merkezi Yayını, Ankara.

Turan, Refik (2004), “İnkılaplar Konusunda Basının Tutumu”, Türkiye Cumhuriyeti Tarihi II, Atatürk Araştırma Merkezi, Ankara, ss. 216-223. 
Turp, Muharrem (2018), “Türkiye'nin Demokratikleşmesinde Bir Mihenk Taşı Basında 1950 Seçimleri”, Çağdaş Türkiye Tarihi Araştırmaları Dergisi, XVIII/37, Güz, ss. 677-714.

Yakar, Serdar (2018), "Emirmahmutoğlu Ali Saim", Kahramanmaraş Ansiklopedisi, Cilt 3, Kahramanmaraş Sütçü İmam Üniversitesi Yayını, No:145, Kahramanmaraş, ss. 318-320.

Yenal, Oktay (2013), Cumhuriyet'in İktisat Tarihi, Türkiye İş Bankası Yayınları, İstanbul.

Yıldız, Nuran (1996), "Demokrat Parti İktidarı ve Basın (1950-1960)", AÜSBF Dergisi, C. 51, S. 1, Ankara, ss. 481-505.

Yücel, M. Serhan (2001), Demokrat Parti, Ülke Kitaplar-10, İstanbul.

Zeyrek, Suat (2012), “Milli Mücadele Yıllarında Maraş'ın Düşünce Yapısı ve Seviyesine Bir Kanıt: Amal-i Milliye Gazetesi”, Uluslararası Osmanlı Dönemi Maraş Sempozyumu, III. Cilt, Kahramanmaraş Belediyesi Yayınları, Kahramanmaraş, ss. 369-382.

\section{Süreli Yayınlar}

Engizek

Demokrasiye Hizmet

Halk Postas 1

Kahraman Yurt

Maraş Vilayet Gazetesi

Maraşın Sesi

Zafer

Cumhuriyet 


\section{Ek-1: Demokrasiye Hizmet, 8 Eylül 1955.}

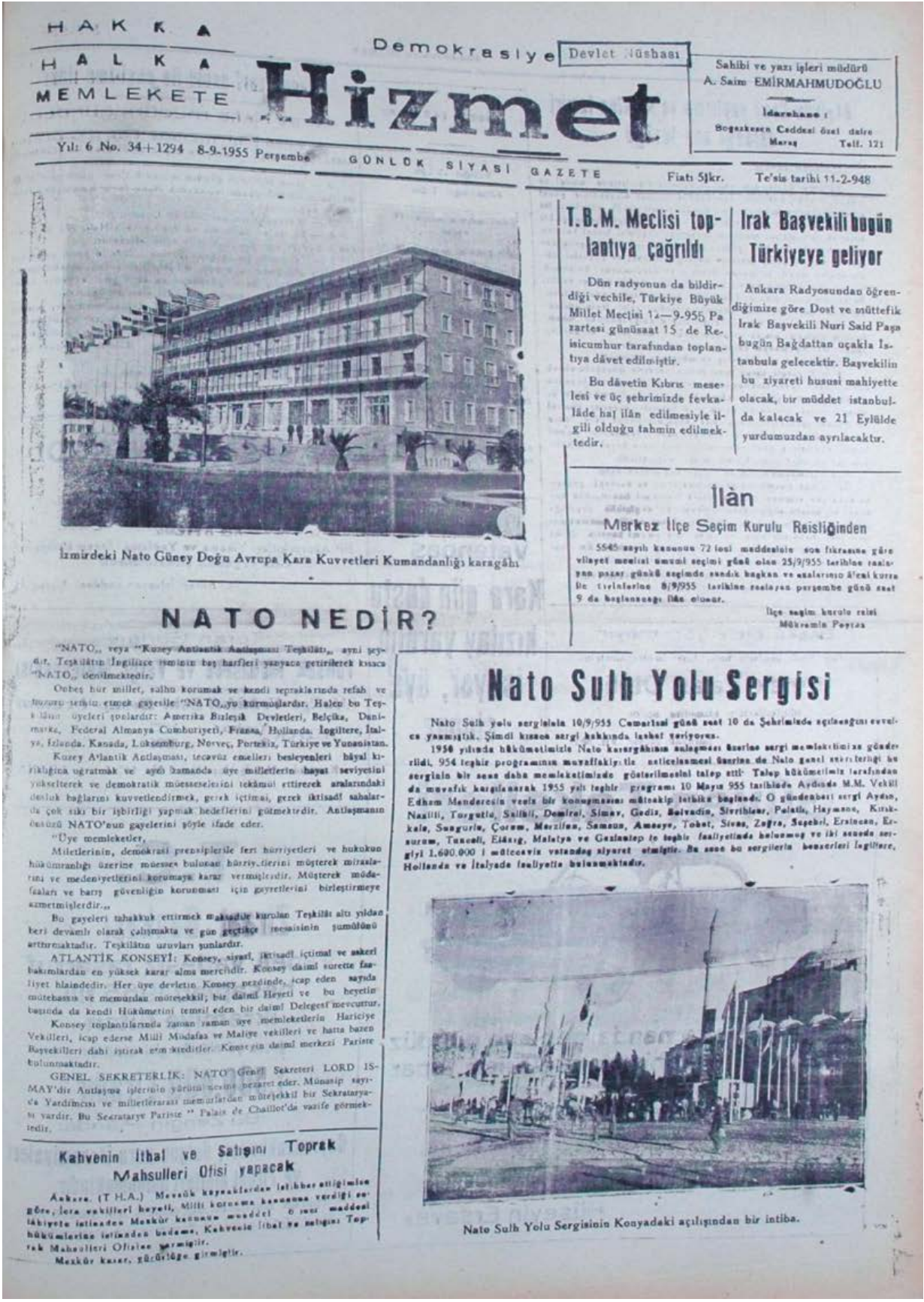




\section{Ek-2: Halk Postası, 17 Ocak 1957.}

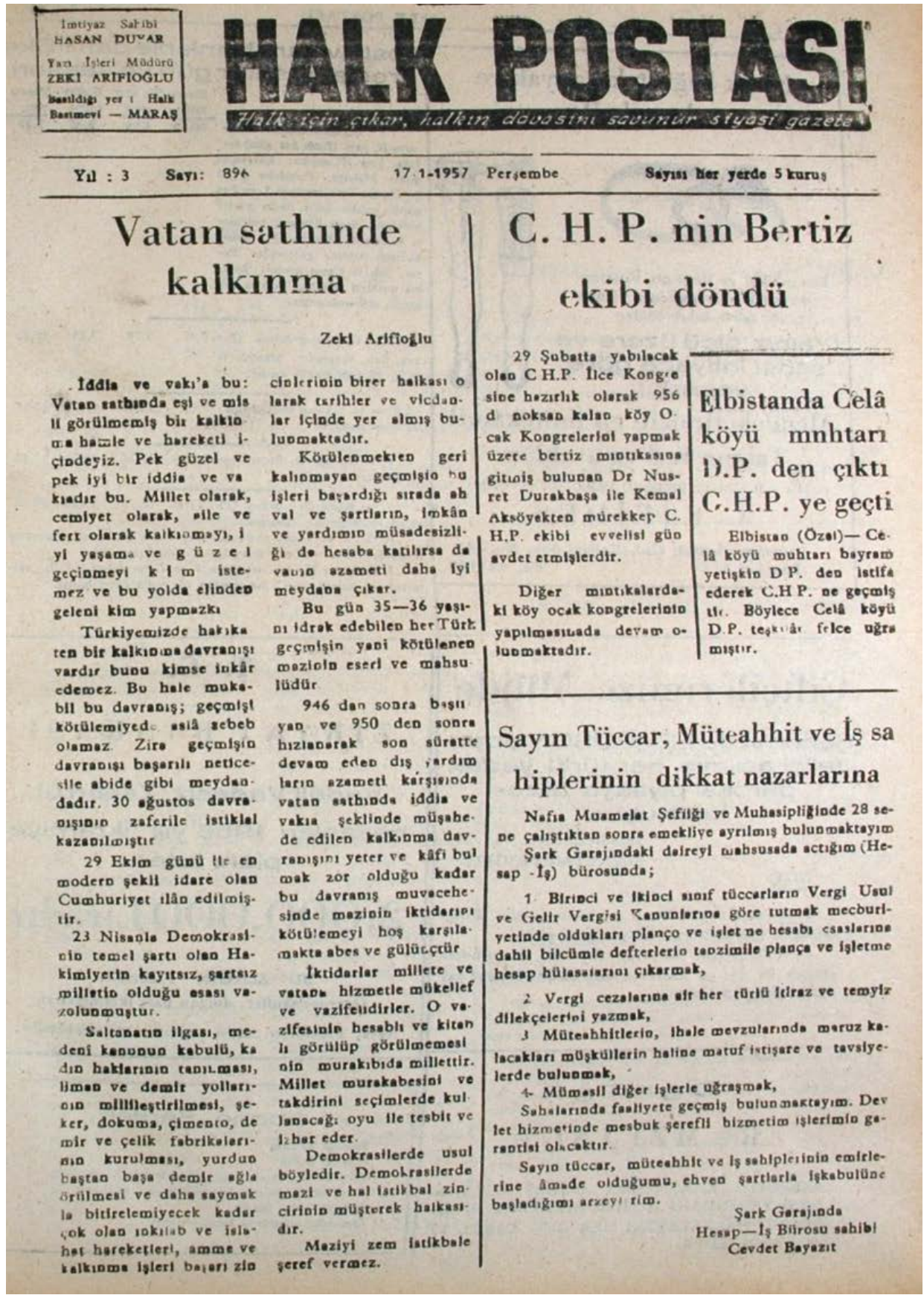

